See discussions, stats, and author profiles for this publication at: https://www.researchgate.net/publication/262961304

\title{
Integration Definition Methods to Support Product Design for Assistive Technology
}

Article in Advanced Materials Research · April 2014

DOI: 10.4028/www.scientific.net/AMR.945-949.434

CITATION

4 authors:

Osiris Canciglieri Jr.

Pontifícia Universidade Católica do Paraná (PUC-PR)

222 PUBLICATIONS 352 CITATIONS

SEE PROFILE

Teófilo Miguel de Souza

São Paulo State University

31 PUBLICATIONS 22 CITATIONS

SEE PROFILE

Some of the authors of this publication are also working on these related projects:

"BIOMIMICRY Global Design Challenge" View project

Sustainable Product Development View project
READS

67

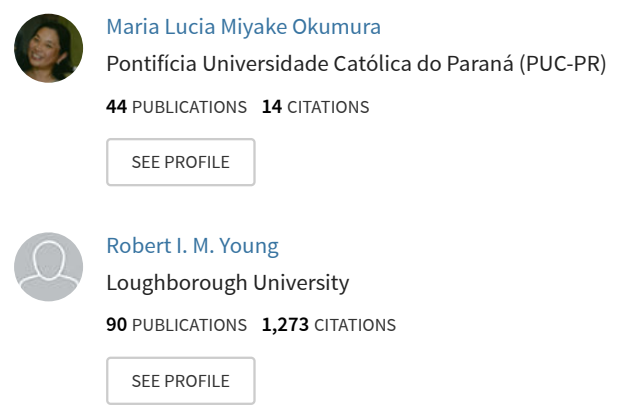




\title{
Integration Definition Methods to Support Product Design for Assistive Technology
}

\author{
Maria Lucia Miyake Okumura, ${ }^{1, a}$, Osiris Canciglieri Junior ${ }^{1, b}$, \\ Teófilo Miguel de Souza ${ }^{2, c}$, Robert I. M. Young ${ }^{3, d}$ \\ ${ }^{1}$ Pontifical Catholic University of Paraná, Polytechnic School, Graduate Program in Production \\ Engineering and Systems - PUCPR/PPGEPS. \\ Rua, Imaculada Conceição 1155, Curitiba, PR, CEP 80215-901 - Brazil. \\ ${ }^{2}$ São Paulo State University - UNESP, Av. Ariberto Pereira da Cunha, 333, Guaratinguetá, São \\ Paulo, Brazil. \\ ${ }^{3}$ Loughborough University, Leicestershire, LE11 3TU, UK.

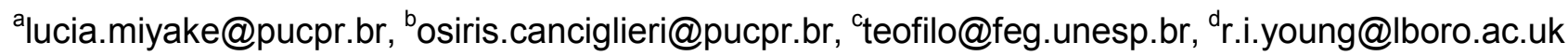

Keywords: Integrated Product Development. IDEF. Assistive Technology. Paralympic Sports Athletes with Visual Disability.

\begin{abstract}
Integrated Product Development Process (IPDP) oriented for Assistive Technology (AT) usually engages multidisciplinary areas for design development. The involvement of professionals from different areas contributes to strengthening the IPDP phases, but a major barrier is the correct interpretation and understanding of the information shared by them, which allows the addressing of the product's requirements and the feeding of the design structure. This paper aims to outline the first steps of the IPDP oriented for TA using the Integrated Definition Methods (IDEF) tool applied to a device design to assist in the training of athletes with visual disabilities. This step of the process focused on Object-Oriented Design Method (IDEF4) and Ontology Capture Method (IDEF5) from IDEF family. The result shows that through the use of the IDEF method oriented for the design of an AT product, the information sharing and the design global aspect to all team members was favored, promoting better communication.
\end{abstract}

\section{Introduction}

The area of Integrated Product Development Process (IPDP) in the Concurrent Engineering environment has strongly contributed in different segments, which ensures aspects of quality, lowest cost, customer satisfaction and maintenance of the market competitiveness. Among different segments, there is the IPDP oriented for Assistive Technology (AT), which presents a systematic approach in the process, involving multidisciplinary areas to meet the requirements of the user who has a physical or sensory limitation. Thus, the involvement of professionals from different areas contributes to strengthening phases the IPDP phases, however, a major barrier is team communication and integration, since it is relevant a correct interpretation and understanding of the information shared by them which allows the addressing of the product's requirements, feed the design structure including its documentation, so that it can be reused in others designs.

The information integration requires control and organization that directs the activities of each area at the appropriate time within the IPDP generating a simultaneous evolution in the design phases without depending on the other stages and time wasting. So that, this research aims to outline the first steps of the IPDP, using the Integrated Definition Methods (IDEF) tool that has an integrated information on Concurrent Engineering approach [1,2,3]. This research developed a device design to assist the training of athletes with visual disabilities based on AT through an exploratory case study. This phase was focused on Object-Oriented Design Method (IDEF4) and Ontology Capture Method (IDEF5) from IDEF family to define in detail the activities, to deep the knowledge of the different areas involved and to investigate the product requirements. 


\section{Background}

Integrated Product Development Process. IPDP oriented for AT aims to extend the product development area to include a user group that is increasingly interacting in the labor market and in the community by the inclusion paradigm. One point of strength is the flexibility that allows changings or substitution of the product characteristics or definition in the design to accommodate different users and ways of use $[5,6,7,8,9]$.

Assistive Technology. AT concept is an area of knowledge "[...] related to the activity and participation of people with disability (PwD) or reduced mobility, aiming their autonomy, independence, quality of life and social inclusion" [10]. Given the comprehensiveness of AT definition, it is considered that AT is classified as products and services which involve the principles of Universal Design, so that the concept was integrated into the accessibility context [11].

Integrated Definition Methods (IDEF). The original structure of the IDEF family was developed by the Defense Department of the U.S. Air Force and presents methods to reduce time of model development, increase communication among members and reuse of knowledge [1]. Among the components of the IDEF family, there are IDEF4 and IDEF5, whose resources are addressed in this study. IDEF4 is an object-oriented design method that relates to "technology creates solutions based on real-world concepts and design creates system focused on quality and maintainability, Which Result in Substantial savings in maintenance costs" [1], and consists of three models: Static Model, Dynamic Model and Behavior Model; and a Design Rationale Component [1]. Thus, the three design models are independent and when interrelating and accompanied by the Design Rationale acquire all information forming a Design Project.

IDEF5 is defined as Ontology Description Capture Method and is directed to: knowledge engineers and experts in each domain that are interested in developing, documenting, storing, and sharing the domain knowledge; system analysts and designers that are interested in managing effectively the ontology knowledge for the purposes of analysis and design; researchers who apply the knowledge representation methods to solve problems in engineering and manufacturing [2].

\section{Proceedings and method Application}

This research is part of a cross-sectional study to follow a sporting device design procedures from AT to assist in the soccer training of athletes visually impaired. The design development team is comprised of teachers, coaches, students and people with visual disabilities. The multidisciplinary areas involved are: Production Engineering, Mechatronics Engineering, Electrical Engineering, Special Education and Physical Education. In this scenery, information is very comprehensive and needs to be categorized in such way that it is structured in the IPDP, especially in the Conceptual design phase. As a consequence of the complexity of interpreting and understanding the volume of information, IDEF 4 and IDEF 5 were used to follow the design proceedings, including the documentation.

Research Methodology. The methodology is applied nature and qualitative approach, since investigates specific phenomenon in a case study with the scientific objective of addressing information from multidisciplinary areas to delineate the phases of the device design in the IPDP oriented for AT.

Technical Procedure. First the design was divided into modules to identify the tasks classification which were structured IPDP. Figure1 detail A illustrates the domain analysis (Internal Design, External Design and Sound Percepcion) and the scope determination. In the sequence were defined the sub-classes and properties [12], illustrated in Figure1detail B. It was approached cases of constraints, such as the type of sound to be implemented in the device. Thereby, one of the relevant phases was the detection of different languages used to survey the user's needs, which are translated into product requirement, as the sound volume and range, whose research added the module Sound Perception. Figure 1 detail C illustrates the formation of the Product Requirements Analysis after the combination of the Design Rationale Component of IDEF4. 


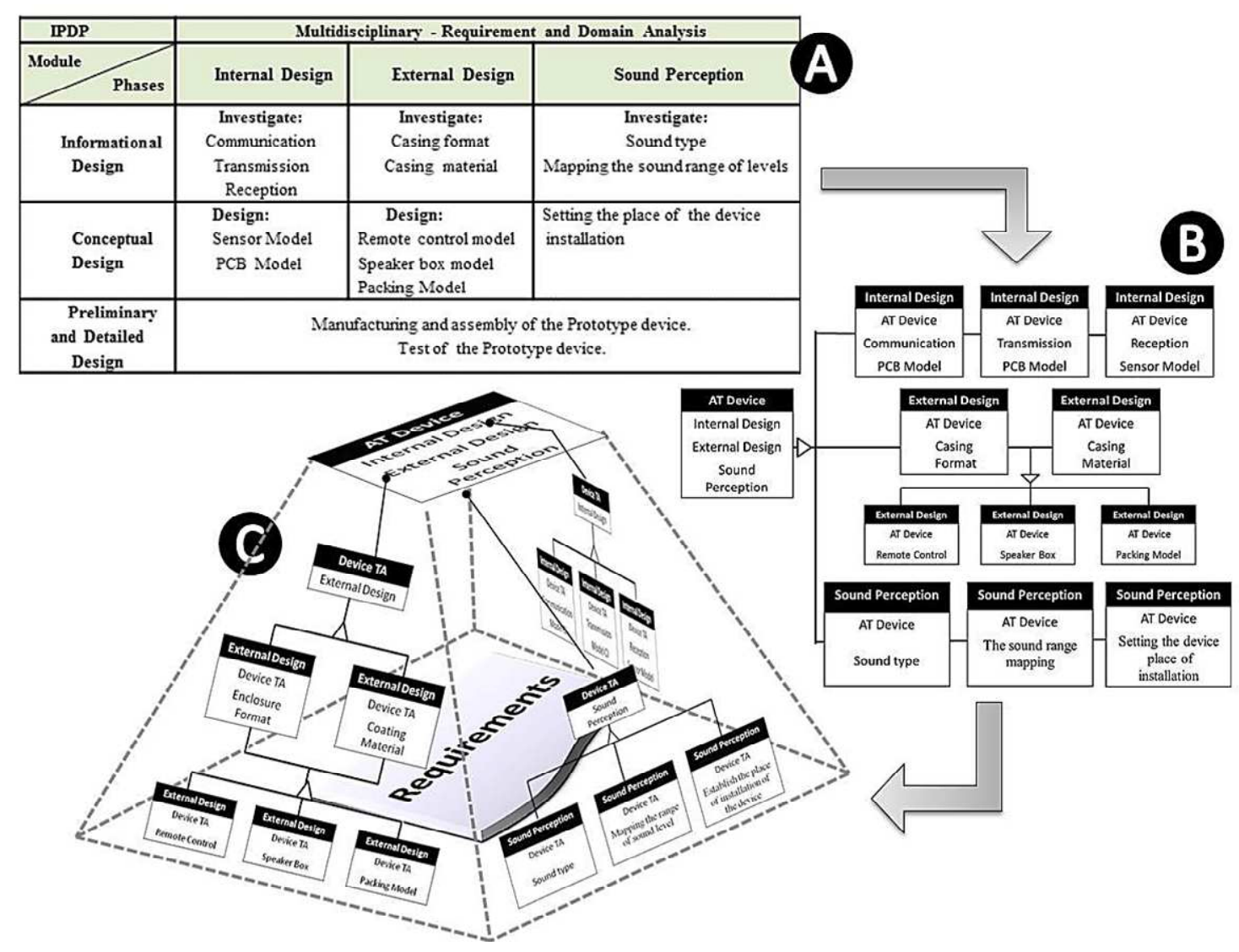

Fig. 1. Application of IDEF4 and IDEF5 in the IPDP oriented for AT.

\section{Result Discussion and Conclusion}

The result shows that through the use of the IDEF method oriented for the design of an AT product, the information sharing and the design global aspect to all team members was favored, promoting better communication. Despite the IDEF family be originally developed for the computational area, the IDEF4, IDEF5 tools has structured the procedures of the tasks in the IPDP in an organized way and with easy visualization, which gives the best practice in the design of product oriented for AT. Thus, it is verified that the IDEF5 in IPDP oriented for AT establishes an ontology practical method, as stated "the intended contribution of IDEF5 is a method to guide and assist domain experts and knowledge engineers in the construction of both small and large reusable ontologies [...] technique to be usable by a personnel at varying skill levels and from a variety of different kinds of organizations" [2].

It is worth clarifying that the design applied in this research is currently underway and in the final stage there will be the a report about the elaboration proceedings of the sporting device, so that it will be possible to replicate the product prototype following the instructions and given conditions to orient the manufacturing process. The use of tools from IDEF family contributed to structure the information and tasks stages as well as to organize the documentation. Therefore, it is recommended to explore other IDEF components to strengthen the information and knowledge of the AT product design in IPDP aiming at further requirement and domain analysis modules.

\section{Acknowledgment}

The authors are thankful for the financial support provided by the Brazilian Government Agency "Coordination for the Improvement of Higher Level Personnel - CAPES", The "National Council for Scientific and Technological Development - CNPq" and the "Pontifical Catholic University of Paraná - PUCPR”. 


\section{References}

[1] R. J. Mayer, D. A. Edwards, L. P. Decker, K. A. Ackley: IDEF4 Techical Report, in: Integrated Information System Evolution Environment, United Sates Air Force AL/HRGA, Wright-Patterson Air Force Base, Ohio, 1991.

[2] P. C. Benjamin, C. P. Menzel, R. J. Mayer, F. Fillion, M. T. Futrell, P. S. De Witte, M. Lingineni: IDEF5 Method Report, in: Integrated Information System Evolution Environment, United Sates Air Force AL/HRGA, Wright-Patterson Air Force Base, University Drive East, Texas, 1994.

[3] R.J. Mayer, M. K. Paintec, P. S. De Witte: IDEF Family of Method for Concurrent Engineering and Business Reengineering Applications, Technical Report, Knowledge Based Systems, Inc., 1994.

[4] K.-Y. Jeong, L. Wu, J.-D. Hong: IDEF method-based simulation model design and development in: Journal of Industrial Engineering and Management, v2n2.p.337-359 (2009).

[5] N. Back, A. Ogliari, A. Dias, J. C. Silva: Projeto integrado de produtos: planejamento, concepção e modelagem. Barueri, SP: Manole (2008).

[6] M. L. M. Okumura: The concurrent engineering applied to the design of integrated product development inclusive: a proposed conceptual framework (in Portuguese). Master Dissertation in Production Engineering and Systems,PUCPR,(2012).

[7] M.Baxter: Projeto de produto: guia prático para o design de novos, 2.ed.rev., São Paulo: Edgard Blücher (2001).

[8] I.Iida: Ergonomia: projeto e produção. 2 ed. revi. and ampl. São Paulo, Edgard Blücher (2005).

[9] M. L. M. Okumura, O. Canciglieri Junior, T. M. Souza: Development process of a method, material and evaluation for professional qualification of employees with disabilities, in: Applied Mechanics and Materials, v 472, pp 990-996, Trans Tech Publications, Switzerland (2014).

[10]Comitê de Ajudas Técnicas, Secretaria Especial Dos Direitos Humanos Da Presidência Da República: Ata da Reunião VII, Brasília (2007).

[11]Associação Brasileira de Normas Técnicas. NBR9050:2004: Acessibilidade a edificações, mobiliário, espaços e equipamentos urbanos, in Comitê Brasileiro de Acessibilidade e Comissão de Edificações e Meio. RJ: ABNT, (2004).

[12] A. Gómez-Pérez: Ontological Engineering, Laboratorio de Inteligencia Artificial Facultad de Informática, Universidad Politécnica de Madrid, Ontological Engineering, IJCAI (1999). 